\title{
Manuscripts, Monks, and Mufattishin: Digital Access and Concerns of Cultural Heritage in the Yale Monastic Archaeology Project
}

\author{
Stephen J. Davis
}

The Yale Monastic Archaeology Project (YMAP) currently sponsors work at two monastic centers in Egypt: at the Shenoutean federation of monasteries near Sohag in the south, and at Wadi al-Națūn (ancient Scetis) in the north. The study of manuscripts at these sites has presented exciting possibilities - and has raised complex challenges - related to digital access and cultural heritage. My contribution to this volume has two parts, and two associated goals. First, I will report on our work at the White Monastery, the central foundation in the Shenoutean federation, where excavations in December 2011 yielded the discovery of manuscript fragments in the Church of St. Shenoute. This discovery served as a catalyst for a series of research steps that began with archaeological analysis and photo-documentation and culminated with the publication of the fragments online through Yale's Egyptological Institute website. Second, I will report on my work cataloguing the Coptic and Arabic manuscripts in the library at the Monastery of the Syrians in Wadi al-Națrūn, a project started in December 2013 that has evolved to include discussions about the possibility of scanning the collection and making its contents available for online access.

In the case of the White Monastery, we are supported by the local community's monastic leadership and by a team of inspectors (in colloquial Egyptian Arabic, mufattishin) representing the Egyptian Supreme Council of Antiquities, also known as the scA. The Supreme Council of Antiquities is the body that grants and renews our archaeological permissions on an annual basis, and the local mufattishin implement the scA's policy at the local level. The situation at the Monastery of the Syrians is different. There, because my research is not archaeological in nature, but rather archival, my cataloguing work in the library is facilitated through a private arrangement with the abbot and head librarian. In this article, my goal is to discuss not only our digitization practices, but also the ways in which these local relationships and institutional structures contextualize and complicate such plans. In so doing, I hope to stimulate 


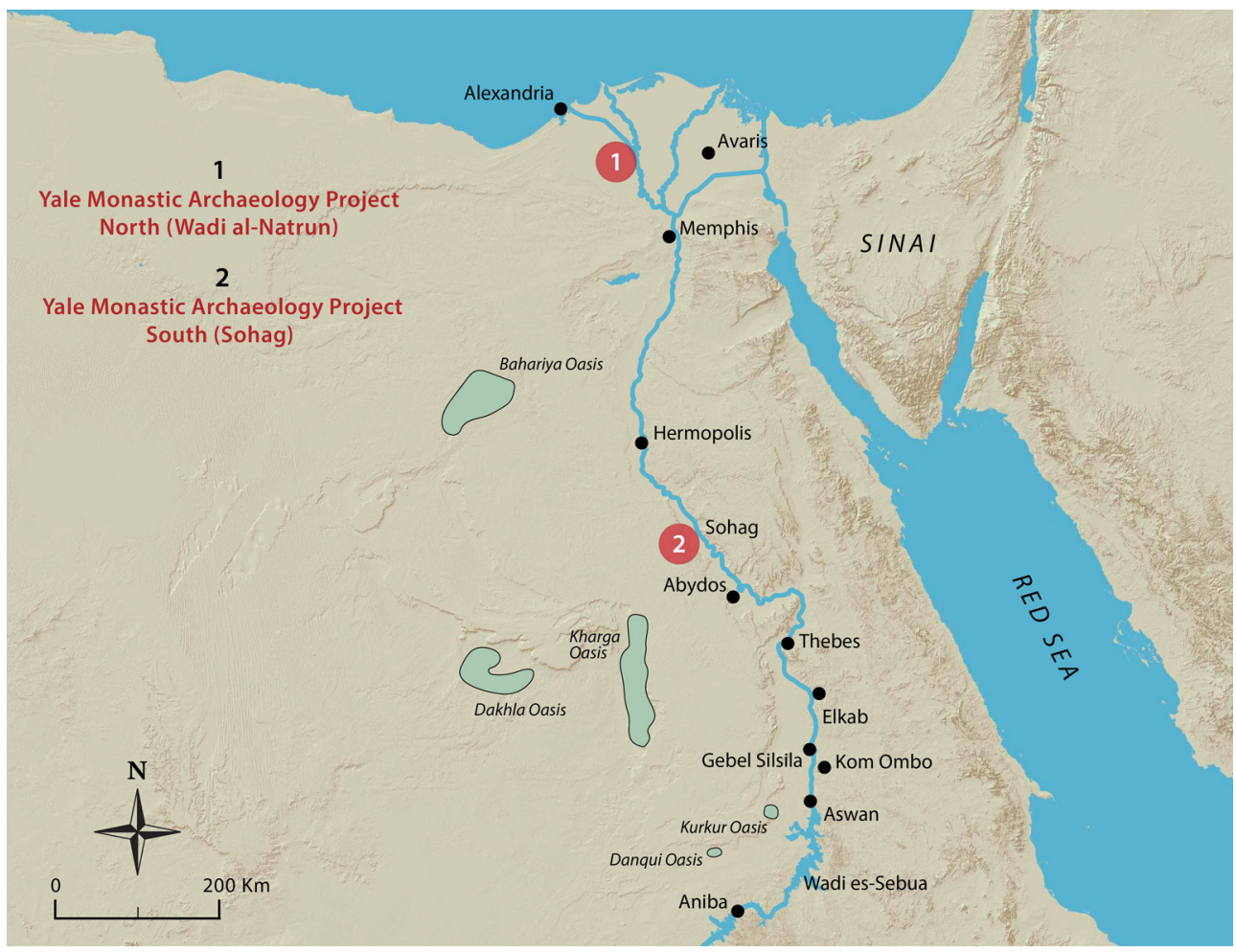

FIGURE 4.1 Map of Egypt, showing the location of the Monastery of the Syrians (Wādī al-Națrūn) and the White Monastery (Sohag). Map created by Alberto Urcia for the Yale in Egypt website: <http://egyptology.yale.edu/expeditions/current-expe ditions $>$. Davis for this publication, accessed on 10.04.19; @STEPHENDAVIS

conversations about cultural heritage, the legacy of colonialism, and the control of manuscript content in the digital age. ${ }^{1}$

1 In the field of cultural heritage management and preservation, there has been a recent upsurge of interdisciplinary reflection on the ethical dimensions of archaeological and archival work, including matters of digitization and digital access: Sandis, Constantine, Cultural Heritage Ethics: Between Theory and Practice, Cambridge: Open Book Publishers, 2014. Ireland, Tracy, Schofield, John, "The Ethics of Cultural Heritage, Ethical Archaeologies," The Politics of Social Justice 4, Gnecco, Cristobal, Ireland, Tracy, eds., New York: Springer / World Archaeological Congress, 2015. Murphy, Bernice L., Museums, Ethics and Cultural Heritage, New York: Routledge, 2016. Such reflection, however, has been noticeably absent in the publications of scholars and projects working with monastic cultural heritage in Egypt, where living religious communities (as well as government agencies) exert claims on historical sites and texts. I hope to draw on the perspectives of "indigenous" and "post-colonial" archaeologies to break this silence. 


\subsection{Infrastructural Challenges from Photography to Digital Database}

During our December 2011 season, the YMAP team conducted excavations in an upstairs space called the "Candle Room" within the monumental fifth-century church at the White Monastery. Located above and to the north of the sanctuary, the room had been used in recent times as a storage space for candles (hence the name). Along with fragments of candles, charcoal, floor plaster, brick, newspaper, cardboard, and modern prayer petitions, our excavations in the room yielded numerous small fragments of parchment and paper with Coptic or Arabic writing, along with pieces of textile and leather associated with book bindings. The following year, I oversaw the photo-documentation and cataloguing of the fragments on site. A co-authored article published in the Journal of Coptic Studies documented our archaeological methodology and presented an initial report on the contents of this find, including one identified fragment from the Canons of Shenoute, the fifth-century head of the community. That article placed the fragments within the context of a long history of manuscript dissemination when the White Monastery library was "dismembered and sold off piecemeal over a span of 125 years, during the eighteenth, nineteenth, and twentieth centuries." ${ }^{2}$

The process of photographing the fragments in December 2012 was made more difficult because of local tensions within the SCA inspectorate and because of changes in our physical working conditions. Prior to the 2012 season, based on a locally negotiated arrangement, we had been able to conduct finds analysis on a regular basis in a dedicated workspace within our rest house. But that year, tensions developed within the local inspectorate, prompted by the visit of a regional inspector who tried to implement a more stringent set of policies (one more closely aligned with written scA statutes). As a result, prior to our planned photo-documentation we were required to relocate our entire finds magazine to a building adjacent to the inspectorate and to perform all our subsequent finds analysis and photography in the inspectorate office space, where the lighting was poor and variable. At the time, these local dynamics made it uncertain what kind of access and authorization we might be granted in the future, and so we felt pressed to complete an entire set of photographs within the short span of that season, despite the suboptimal conditions. I completed this work with the assistance of three graduate students, Elizabeth Davidson, Daniel Schriever, and Mary Farag.

2 Davis, Stephen J. et al., "Left Behind: A Recent Discovery of Manuscript Fragments in the White Monastery Church," Journal of Coptic Studies 16, 2014, 69-87, quote p. 79. 
We faced a different set of infrastructural challenges in moving from photography to the development of an online database. Making the images of the Candle Room fragments freely available to other researchers online was understood to be part of our contractual responsibility to the SCA and part of our partnership with the monastery in preserving its cultural heritage. To this end, our aim was to create an accessible, uniform interface through the Yale in Egypt website. With this objective in mind, I worked with Mary Farag and with the website's designer and manager, Bjorn Akselsen, to format the images and to find software that accommodated different user environments, taking into account variables introduced by hardware, operating systems, mobile devices, browsers, etc.

We had 1850 images in total, and to format them we decided to juxtapose each separate recto and verso in a single, unified image file. The result was 925 slides instead of 1850 . Due in part to the suboptimal photographic conditions on site, the images revealed certain variations in quality, lightness/contrast, and proportion. Thus, to prepare the composites required a multi-step approach: we adjusted lightness and contrast, and then resized and reconfigured images to achieve uniformity across the entire collection. Once the composites were prepared, the resulting images were optimized in Photoshop. Finally, the high-resolution images were reduced to about ten percent of original size, without reducing image quality for online viewing.

In preparation for making the images available to the general public, we ran tests and decided on a simple yet advanced "slide-show" gallery presentation using an application called SimpleViewer-Pro. ${ }^{3}$ This software had a pleasing interface, allowed for Universal Playback, and provided a considerable amount of control and flexibility. The system went live in December 2014. Unfortunately, however, we subsequently were forced to change the delivery method as Yale University moved to a different content management system called Drupal $^{\mathrm{m}}{ }^{\mathrm{N}} 4$ The built-in "slide-show" capabilities of Drupal ${ }^{\mathrm{mt}}$ proved to be less customizable than SimpleViewer, and as a result we had much less control over the image display. Despite this temporary setback, Bjorn Akselsen worked

3 For more information on the SimpleViewer-Pro application, see: $<\mathrm{https} / /$ www.simpleviewer. net/simpleviewer/pro/>, accessed 10.04.19.

$4 \mathrm{Drupal}^{\mathrm{m} \text { in }}$ is an open source software platform used to create websites and online applications, see: <https://www.drupal.org>, accessed November 22, 2017, and Nick Abbott, Richard Jones, Matt Glaman, and Chaz Chumley, Drupal 8: Enterprise Web Development (Olton, U K: Packt Publishing, 2016). 




FIGURE 4.2 Screenshot of the former interface for the Candle Room Manuscript fragments in SimpleViewer-Pro. <https://egyptology.yale.edu/current-expeditions/yale-monas tic-archaeology-project-south-sohag/white-monastery/candle-room-manuscriptfragments $>$. Accessed on 10.04.19; (C) STEPHENDAVIS

with Yale's technology department to transfer our content to the new system and in the end managed to approximate its original functionality. ${ }^{5}$

\section{The Manuscript Library at the Monastery of the Syrians}

\subsection{Cultural Heritage and Local Concerns about Digitization}

Having reviewed the process by which the White Monastery Candle Room fragments were digitized, I now turn to a second case study: the manuscript

5 I want to thank Bjorn Akselsen for his expertise in website development and his assistance in reporting on the details of this process, and Mary Farag for her invaluable help in formatting the images. 


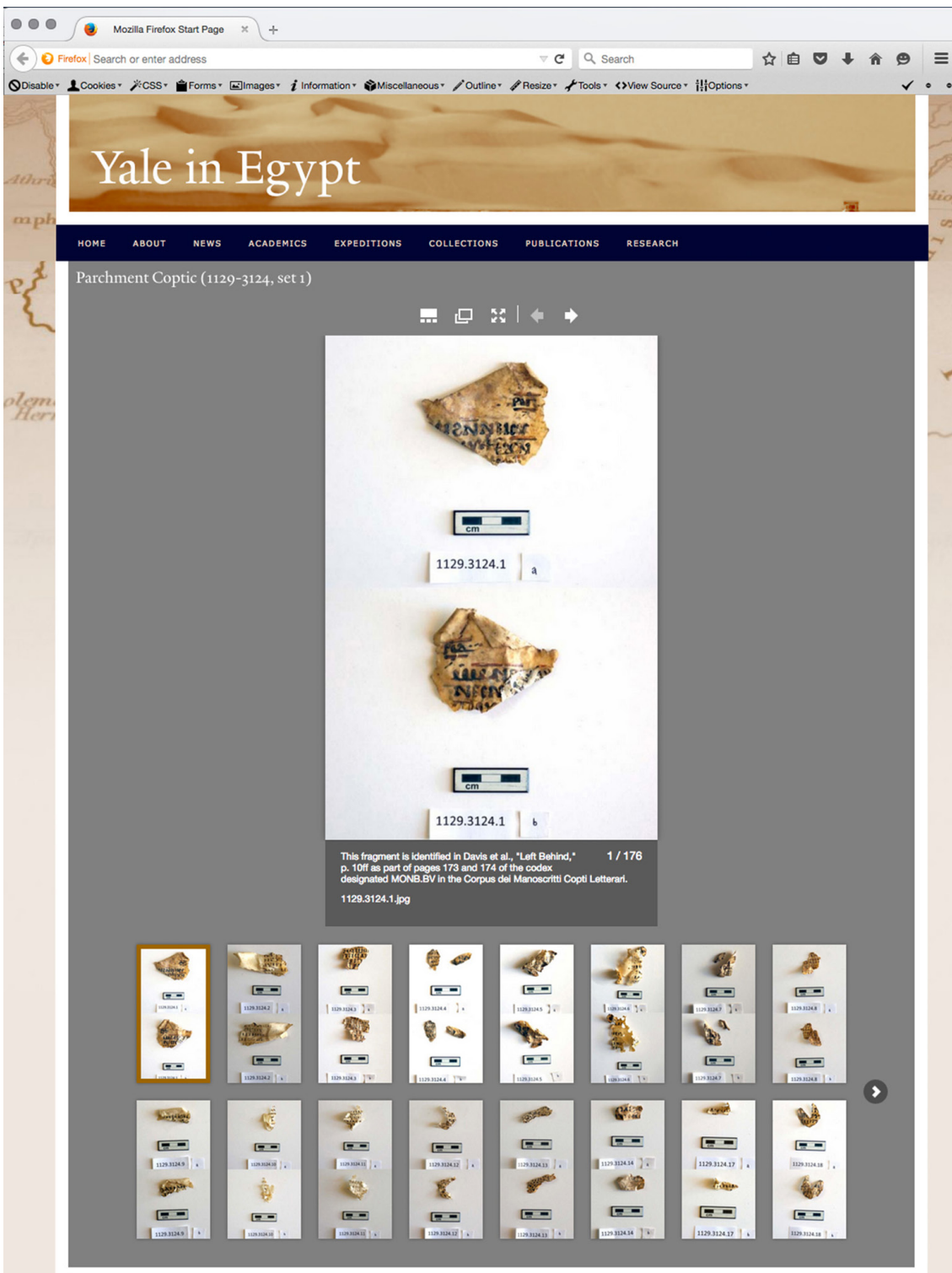

Yale Copyright @ 2015 Yale University · All rights reserved . Privacy policy

FIGURE 4.3 Screenshot of the current interface for the Candle Room Manuscript fragments in Drupal $^{\mathrm{m}}$. Drupal $\mathrm{l}^{\mathrm{m}}<$ https://egyptology.yale.edu/archaeological-expeditions/ white-monastery-project/candle-room-project/parchment_coptic_1129-3124_ set_1>, accessed on 10.04.19; (OSTEPHENDAVIS 
library at the Monastery of the Syrians in Wādī al-Națūn. Since December 2013, I have been cataloguing the corpus of Coptic and Arabic manuscripts in the collection. This work follows a previous project by Sebastian Brock and Lucas Van Rompay to catalogue the Syriac manuscripts and fragments, the results of which were published in 2014 by Peeters Press. ${ }^{6}$ Taken together, the Syriac, Coptic, Arabic, and Ethiopic holdings of the library number more than 1000. Of these, approximately 800 manuscripts are Coptic, Arabic, or a bilingual mix of Coptic and Arabic. As of June 2017, my team and I have logged almost 2000 person-hours in the library and have produced comprehensive catalogue entries for over 300 manuscripts in the Coptic and Arabic collections. This work has been facilitated by the kind hospitality of Bishop Mattā'us, the abbot of the monastery, Father Bigoul, the former head librarian, and Fathers Amoun and Azer (Lazarus), the current librarians. ${ }^{7}$

The hospitality of the monastery and especially my conversations with Father Bigoul provide the context for my reflections here on cultural heritage management and digitization. Our conversations evolved in stages, as Father Bigoul moved from a posture of suspicion and resistance to one of cautious optimism and cooperation. When I began my cataloguing work at the monastery, I initially inquired about whether photography and/or digitization should be considered part of my larger project, and at that time Father Bigoul made it clear (in no uncertain terms) that this topic was effectively off limits. To underscore his objection, he shared with me two stories about recent visitors to the monastery who had betrayed his trust. In one case, he had allowed someone to photograph a manuscript with the promise that it was only for personal use, but a few months later another visitor came to the monastery with a CD he had

6 Brock, Sebastian, Van Rompay, Lucas, Catalogue of the Syriac Manuscripts and Fragments in the Library of Deir al-Surian, Wadi al-Natrun (Egypt), Orientalia Lovaniensia Analecta 227, Louvain: Peeters, 2014.

7 For a preliminary summary of this work, see Davis, Stephen J., "Cataloguing the Coptic and Arabic Manuscripts in the Monastery of the Syrians: A Preliminary Report," in: Studia Patristica XCII: Papers Presented at the Seventeenth International Conference on Patristic Studies, held in Oxford 2015, Volume 18, Markus, Vincent, 2017, Louvain: Peeters, 179-185. More recently, I have presented three reports updating our progress, with a special focus on the biblical collection and on historical information gleaned from scribal and readerly insertions in those manuscripts, at the Eleventh International Congress of Coptic Studies (Claremont, CA, July 2016), at the 2016 Society of Biblical Literature Annual Meeting (San Antonio, TX, November 2016), and at the Oxford seminar, New Perspectives on Mediterranean History (Balliol College, Oxford University, June 2017). These presentations formed the basis of a new article entitled "Marginalia Coptica et Arabica: Traces of Scribes, Patrons, Restorers, and Readers in the Biblical Collection at the Monastery of the Syrians (Dayr al-Suryān)," to be published in: Proceedings of the Eleventh International Congress of Coptic Studies, Claremont, CA, July 25th-3oth 2016, Louvain: Peeters, 2019, forthcoming. 
acquired containing the same images. In another case, a scholar visiting the library for manuscript study had pledged not to take photographs, but later Father Bigoul returned to find the person snapping pictures. These anecdotes are part of the monks' shared cultural memory of a colonialist history in which the monastery has lost agency over large portions of its manuscript collection: the majority of its Syriac holdings were purchased and carted away by the Vatican in the eighteenth century and by the British Library in the nineteenth century.

Over our first year of work, it became clear that the number of manuscripts in the collection would require multiple volumes, and during this period Father Bigoul and I spoke frequently about the format, organization, and logistics related to our publication plans. As part of this ongoing conversation, in December 2014, I asked about the possibility of photographing sample folia for inclusion as illustrative figures in those volumes, just as Brock and Van Rompay had done for their Syriac catalogue. Father Bigoul was happy to facilitate this, and to my surprise he also broached the subject of digitization, telling me that making the collection available online was now a priority of his.

When I asked why his mind had changed, he told me that he had been cautious earlier because of his experiences of being "burned" by betrayals of trust. He also revealed that he had been approached in the recent past by another North American academic institution interested in entering into a contract with the monastery to digitize the collection. But the terms of the proposed contract caused him considerable discomfort, primarily because of the way copyright control was construed. While the American institution offered to provide equipment, and to undertake all the digitization work itself, it wanted to charge a fee to anyone requesting use of the images. This fee would be payable not to the monastery but to the partner library in the United States. Father Bigoul did not feel comfortable with this kind of financial structure: instead, he

8 On the history of the library at the Monastery of the Syrians, see Father Bigoul al-Suriany, "The Manuscript Collection of Deir al-Surian in Wadi al-Natrun," Journal of the Canadian Society for Coptic Studies 2.1, January 2011, 51-62 (available online with a subscription at <http://lock woodonlinejournals.com/>, accessed on 10.04.19. See also Sebastian Brock and Lucas Van Rompay, Catalogue of the Syriac Manuscripts and Fragments, xiii-xxii. For examples of manuscripts from the Monastery of the Syrians now housed in other collections, see Wright, William, Catalogue of Syriac Manuscripts in the British Museum acquired since the year 1838, 3 vols., London: British Museum, 1870-1872. Wright, William, Notulae Syriacae, London: Gilbert and Rivington, 1887. Assemani, Joseph Simeon, Assemani, Stephanus Evodius, Biblioteca apostolicae vaticanae codicum manuscriptorum catalogus in tres partes, vols. 2-3, Paris: Maisonneuve, 1926. Tisserant, Eugenius, Specimina Codicum Orientalium, in: Lietzmann, J., Tabulae in Usum Scholarium, Bonn: Marcus and Weber, 1914. Hatch, William H.P., An Album of Dated Syriac Manuscripts, Boston: The American Academy of Arts and Sciences, 1946. 
preferred to facilitate free access. The proposed contract also stipulated that copyright ownership would be shared between the American institution and the monastery and that each would possess a copy of the digital database, but Father Bigoul was concerned that in practice the agency of the monastery would be trumped by the American institution if there was a disagreement on terms of permission. As a result, Father Bigoul had come away with significant reservations about entering such partnerships.

In this context, I want to draw on some helpful insights from scholars working in the area of digitization and cultural heritage studies. As I alluded to earlier, Father Bigoul's reservations are in fact deeply embedded in cultural memories of "epistemic violence" and "the loss of Indigenous control over use

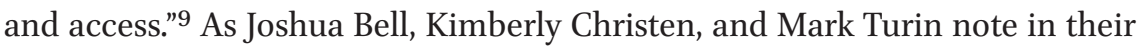
introduction to a volume on "Digital Repatriation and the Circulation of Indigenous Knowledge," it is "precisely because [digital] materials can exist in multiple locations" that there has been a shift of emphasis from "issues of access to access and control." It is because "digital objects can co-exist in Indigenous archives and websites as well as in institutional databases (online or off)" that communities like the Monastery of the Syrians raise valid "concerns over who makes decisions about how materials are accessed, circulated, and understood across multiple settings." ${ }^{10}$ As Kate Hennessy and her colleagues working on "The Inuvialuit Living History Project" have recognized, this is where "forging relationships" and "establishing the groundwork for clear and meaningful communication" lay the foundation for "trust, respect, and solidarity," and for the kind of "openness and flexibility that is grounded in ... the value of curatorial collaboration with originating communities."11

9 Anderson, Jane, Christen, Kim, "'Chuck a Copyright on It': Dilemmas of Digital Return and the Possibilities for Traditional Knowledge Licenses and Labels," Museum Anthropology Review 7.1-2, Spring-Fall, 2013, 105-126, p. 113. In drawing on the category of "Indigeneity" and applying it to the Coptic community in Egypt, I employ it not as an absolute category, but as "relational," "variable," and "defined relative to encounters with people newer to a place": see Colwell-Chanthaphonh, Chip, "Archaeology and Indigenous Collaboration," in: Archaeological Theory Today, Hodder, Ian, ed., second edition, Cambridge: Polity, 2012, 267-91, p. 279; quoting in part from Wobst, Martin H., "Indigenous Archaeologies: A Worldwide Perspective on Human Materialities and Human Rights," in: Indigenous Archaeologies: A Reader on Decolonization, Bruchac, Margaret M., Hart, Siobhan M., Wobst, Martin H., eds., Walnut Creek, CA: Left Coast Press, 2010, 17-27, p. 19. Bell, Joshua A., Christen, Kimberly, Turin, Mark, "Introduction: After the Return," Museum Anthropology Review 7.1-2, Spring-Fall, 2013, 1-21, p. 7.

11 Hennessy, Kate, Lyons, Natasha, Loring, Stephen, Arnold, Charles, Mervin, Joe, Elias, Albert, Pokiak, James, "The Inuvialuit Living History Project: Digital Return as the Forging of Relationships Between Institutions, People, and Data," Museum Anthropology Review 7.1-2, Spring-Fall 2013, 44-73, at 59 and 62. Here, the authors draw on the work of Jürgen 
In my case, I had forged a longstanding relationship with the Monastery of the Syrians over the course of almost a decade of archaeological and archival work in the region. Starting in 2006, during our excavation seasons nearby at the site of the Monastery of John the Little, the Monastery of the Syrians had housed our Egyptian workers, and the nearby Monastery of St. Bishoi provided space for our finds magazine. Beginning in 2013, as part of the cataloguing project, Father Bigoul and I began working intensively side-by-side in the library and engaged in many conversations on personal and professional matters. Thus, when I asked him why his mind had changed, he told me that this durative experience of collegiality and mutual investment was what allowed him to overcome his initial reservations about the prospect of collaborating on a digitization initiative. For my part, any such discussions had to hinge on an appropriate sensitivity to the enduring effects of Egypt's colonialist legacy, including the need to acknowledge and act responsibly in the face of institutional inequities when it comes to financial resources, and above all to ensure and preserve the monastery's agency in determining how best to manage its own cultural heritage. ${ }^{12}$ This is consistent with the wider disciplinary goal in cultural heritage management of "equalizing power relationships and creating mutually beneficial projects"13 and of attending to the "ethical implications... [and] politics of fieldwork, and collaborations with local people, descendants, indigeneous groups, and other communities of connection."14

After the December 2014 season, we began a process of careful deliberation involving experts from Yale, from the Bibliotheca Alexandrina, and from the Monastery of the Syrians. From April 27 to May 1, 2015, Father Bigoul paid a visit to Yale University in New Haven, CT, for a week of consultations. During

Habermas' interlinked concepts of "communicative action" and "communicative space". See: Habermas, Jürgen, The Theory of Communicative Action, 2 vols., McCarthy, Thomas, trans., Boston: Beacon Press, 1984-1989; McCarthy, Thomas, Between Facts and Norms: Contributions to a Discourse Theory of Law and Democracy, Rehg, William, trans., Studies in Contemporary German Social Thought, Cambridge, Mass.: MIT Press, 1996.

On the importance of cultivating and maintaining "an awareness of colonial histories, in terms of both their material and economic impacts and of the forms of thought which the colonial world produced," see: Gosden, Chris, "Post-Colonial Archaeology," in: Archaeological Theory Today, Hodder, Ian, ed., second edition, 251-266, quote p. 252. Colwell-Chanthaphonh, Chip, "Archaeology and Indigenous Collaboration," 273. Meskell, Lynn, "The Social Life of Heritage," in: Archaeological Theory Today, Hodder, Ian, ed., second edition, 229-25o, p. 235. On the ethical dimensions of fieldwork, see also Hall, Martin, "Situational Ethics and Engaged Practice: The Case of Archaeology in Africa," in: Embedding Ethics: Shifting the Boundaries of the Anthropological Profession, Meskell, Lynn M., Pels, Peter, eds., Oxford: Berg, 2005, 169-184. Zimmerman, Larry J., Vitelli, Karen D., Hollowell-Zimmer, Julie, eds., Ethical Issues in Archaeology, Walnut Creek, CA: AltaMira, 2003 . 
his stay, he met with Beth Beaudin, a librarian with extensive experience in the digitization of Middle Eastern library collections, including prior collaboration with the Bibliotheca Alexandrina. He also paid visits to the photography lab at Yale, the Beinecke Rare Book and Manuscript Library, and the Manuscripts and Archives department of Sterling Memorial Library, including a meeting with Robin Dougherty, the curator for the Arabic language collection. The result of these appointments was deeper knowledge of the different methodologies and equipment utilized at Yale for digitization projects. In the end, Father Bigoul decided that a high-resolution scanner with an adjustable cradle would best suit his needs at the monastery, since it would allow for maximum efficiency and scanning speed, while preserving the integrity of the physical manuscripts, many of which have fragile bindings. During our subsequent cataloguing season at the Monastery of the Syrians, in June 2015, Father Bigoul also hosted a consultation with representatives from the Bibliotheca Alexandrina, who agreed to provide technical expertise, training, and supervision, once the equipment has been purchased (not a small task given that the desired scanner costs upwards of $\$ 50,000$ ). Since then we have been exploring possible avenues for funding that would allow the monastery to purchase this equipment and begin the work of digitization, although Father Bigoul's recent retirement in the fall of 2016 has meant that these plans will need to be reassessed and reinitiated under the new library leadership.

What I hope to have conveyed in this article is the importance of context for determining the limitations and potentialities of digitization efforts connected with archaeological and archival work in Egypt. The Candle Room fragments discovered in the White Monastery church and the manuscripts in the library at the Monastery of the Syrians are not simply texts studied in an empirical vacuum; they are also "objects embedded in a nexus of social relations." ${ }^{15}$ The cultural heritage of these sites is tenuously balanced among three stakeholders: the monks themselves, the Egyptian government (represented by team of mufattishin at the local inspectorate), and the foreign institutional partner

15 Bell, Joshua A., Christen, Kimberly, Turin, Mark, "Introduction: After the Return," 3. In their article, the authors are interested in mining the "relational" aspect of museums, collections, and objects - what Tim Ingold has termed "meshworks", see: Ingold, Tim, Lines, A Brief History, London: Routledge, 2007 also Gosden, Chris, Larson, Frances, Petch, Alison, Knowing Things: Exploring the Collections at the Pitt Rivers Museum, 1884-1945, Oxford: Oxford University Press, 2007. 
or partners. In the case of the White Monastery, the Candle Room fragments themselves are a material product of the colonialist history of dissemination I referred to earlier: they were literally "left behind" when the manuscripts were removed for sale. The process of photographing and digitizing those same fragments was conditioned by present-day relational tensions in the local inspectorate and by shifting infrastructural conditions, both on site and off. In the case of the Monastery of the Syrians, Father Bigoul's concerns that digitization might result in a loss of control over cultural heritage were shaped by a similar colonialist legacy. To avoid the many pitfalls of this legacy is not an easy task, but there is one desideratum that must certainly guide the ongoing conversations between monastery and university. Energy and attention must be given not only to making decisions about important technical details related to equipment and online presentation, but also to cultivating a mutually responsible relational context - one in which universal access is facilitated, and in which the monastery retains agency over its own collection in both its physical and digital forms.

\section{References}

Anderson, Jane, Christen, Kim, "'Chuck a Copyright on It': Dilemmas of Digital Return and the Possibilities for Traditional Knowledge Licenses and Labels," Museum Anthropology Review 7.1-2, Spring-Fall, 2013, 105-126.

Assemani, Joseph Simeon, Assemani, Stephanus Evodius, Biblioteca apostolicae vaticanae codicum manuscriptorum catalogus in tres partes, vols. 2-3, Paris: Maisonneuve, 1926.

Bell, Joshua A., Christen, Kimberly, Turin, Mark, "Introduction: After the Return," Museum Anthropology Review 7.1-2, Spring-Fall, 2013, 1-21.

Brock, Sebastian, Van Rompay, Lucas, Catalogue of the Syriac Manuscripts and Fragments in the Library of Deir al-Surian, Wadial-Natrun (Egypt), Orientalia Lovaniensia Analecta 227, Louvain: Peeters, 2014.

Colwell-Chanthaphonh, Chip, "Archaeology and Indigenous Collaboration," in: Archaeological Theory Today, Hodder, Ian, ed., second edition, Cambridge: Polity, 2012, 267-291.

Davis, Stephen J. et al., "Left Behind: A Recent Discovery of Manuscript Fragments in the White Monastery Church," Journal of Coptic Studies 16, 2014, 69-87.

Davis, Stephen J. et al., "Cataloguing the Coptic and Arabic Manuscripts in the Monastery of the Syrians: A Preliminary Report," in: Studia Patristica xcII:Papers Presented at the Seventeenth International Conference on Patristic Studies, held in Oxford 2015, Volume 18, Vincent, Markus, ed. 2018, Louvain: Peeters, 179-185. 
Davis, Stephen J. et al., "Marginalia Coptica et Arabica: Traces of Scribes, Patrons, Restorers, and Readers in the Biblical Collection at the Monastery of the Syrians (Dayr al-Suryān)," in: Proceedings of the Eleventh International Congress of Coptic Studies, Claremont, CA, July 25th-3oth, 2016, Louvain: Peeters, 2019, forthcoming.

Father Bigoul al-Suriany, "The Manuscript Collection of Deir al-Surian in Wadi al-Natrun," Journal of the Canadian Society for Coptic Studies 2.1, January 2011, 51-62 (available online with a subscription at <http://lockwoodonlinejournals.com/>), accessed on 10.04.19.

Gosden, Chris, "Post-Colonial Archaeology," in: Archaeological Theory Today, Hodder, Ian, ed., second edition, 251-266.

Gosden, Chris, Larson, Frances, Petch, Alison, Knowing Things: Exploring the Collections at the Pitt Rivers Museum, 1884-1945, Oxford: Oxford University Press, 2007.

Habermas, The Theory of Communicative Action, 2 vols., McCarthy, Thomas, trans., Boston: Beacon Press, 1984-1989.

Habermas, Between Facts and Norms: Contributions to a Discourse Theory of Law and Democracy, Rehg, William, trans., Studies in Contemporary German Social Thought, Cambridge, Mass.: MIT Press, 1996.

Hall, Martin, "Situational Ethics and Engaged Practice: The Case of Archaeology in Africa," in: Embedding Ethics: Shifting the Boundaries of the Anthropological Profession, Meskell, Lynn M., Pels, Peter, eds., Oxford: Berg, 2005, 169-184.

Hatch, William H.P., An Album of Dated Syriac Manuscripts, Boston: The American Academy of Arts and Sciences, 1946.

Hennessy, Kate, Lyons, Natasha, Loring, Stephen, Arnold, Charles, Mervin, Joe, Elias, Albert, Pokiak, James, "The Inuvialuit Living History Project: Digital Return as the Forging of Relationships Between Institutions, People, and Data," Museum Anthropology Review 7.1-2, Spring-Fall 2013, 44-73.

Ireland, Tracy, Schofield, John, "The Ethics of Cultural Heritage, Ethical Archaeologies," The Politics of Social Justice 4, Gnecco, Cristobal, Ireland, Tracy, eds., New York: Springer / World Archaeological Congress, 2015.

Meskell, Lynn, "The Social Life of Heritage," in: Archaeological Theory Today, Hodder, Ian, ed., second edition, 229-250.

Murphy, Bernice L., Museums, Ethics and Cultural Heritage, New York: Routledge, 2016. Sandis, Constantine, Cultural Heritage Ethics: Between Theory and Practice, Cambridge: Open Book Publishers, 2014.

Tisserant, Eugenius, Specimina Codicum Orientalium, in: Lietzmann, Johannis., Tabulae in Usum Scholarum, eds., Bonn: Marcus and Weber, 1914.

Wobst, Martin H., "Indigenous Archaeologies: A Worldwide Perspective on Human Materialities and Human Rights," in: Indigenous Archaeologies: A Reader on Decolonization, Bruchac, Margaret M., Hart, Siobhan M., Wobst, Martin H., eds., Walnut Creek, CA: Left Coast Press, 2010, 17-27, at 19. 
Wright, William, Catalogue of Syriac Manuscripts in the British Museum acquired since the year 1838, 3 vols., London: British Museum, 1870-1872.

Wright, William, Notulae Syriacae, London: Gilbert and Rivington, 1887.

Zimmerman, Larry J., Vitelli, Karen D., Hollowell-Zimmer, Julie, eds., Ethical Issues in Archaeology, Walnut Creek, CA: AltaMira, 2003. 
PART 2

Data Mining and Visualisation 